\title{
Dampak Pelanggaran Batas Waktu Pembentukan Peraturan Pelaksana Undang-Undang Nomor 18 Tahun 2017 tentang Pelindungan Pekerja Migran Indonesia
}

\section{Impact of Violation of Time Limits for the Establishment of Implementing Regulations for Law Number 18 of 2017 on the Protection of Indonesian Migrant Workers}

\author{
Luthvi Febryka Nola \\ Pusat Penelitian Badan Keahlian Sekretariat Jenderal DPR RI \\ Gedung Nusantara 1 Lantai 2, DPR RI \\ Jl. Jenderal Gatot Subroto, Senayan, Jakarta \\ Email: luthvi.nola@dpr.go.id \\ Naskah diterima: 3 Agustus 2020 \\ Naskah direvisi: 28 September 2020 \\ Naskah diterbitkan: 1 November 2020
}

\begin{abstract}
Law No. 18 of 2017 on the Protection of Indonesian Migrant Workers (PIMW Law) mandates the formulation of a number of implementing regulations within a period of 2 (two) years since the enactment of the Law. However, only 3 (three) implementing regulations were successfully promulgated within the scheduled time period. While the rest, some are behind schedule, and some have yet to be drafted. To overcome this, the government exercised discretion while still enforcing the former regulations. This paper discusses some impacts of failure to meet the deadline for the formulation of implementing regulations from the PIMW Law and identification of some efforts to overcome these impacts. The writing method used is juridical normative through library studies of secondary data for descriptive qualitative analysis. From the discussion, it is known that the cause of failure to meet the deadline for the formation of implementing regulations is the technical and material constraints of the regulations. The failure to meet the deadline lead to failure in implementing most of the provisions in the PIMW Law and affecting the process of protecting Indonesian migrant workers (IMW), not only before, but also during and after working abroad, such as the imposition of placement fees; existing shelter which is the source of the Covid-19 transmission; and the rampant practice of IMW seafarers' slavery. Therefore, all implementing regulations of the PIMW Law need to be promulgated. The House, through its supervisory function, both in the Commission and the IMW Supervisory Team, needs to continue to urge the government to establish implementing regulations for the PIMW Law.
\end{abstract}

Keywords: failure to meet the deadline; establishment of implementing regulations; Indonesian Migrant Workers; cause; impact

\begin{abstract}
Abstrak
UU No. 18 Tahun 2017 tentang Pelindungan Pekerja Migran Indonesia (UU PPMI) mengamanatkan pembentukan sejumlah aturan pelaksana dalam jangka waktu dua tahun sejak UU tersebut diundangkan. Akan tetapi hanya tiga aturan pelaksana yang berhasil diundangkan dalam jangka waktu tersebut. Sedangkan sisanya, ada yang terlambat dan ada yang belum terbit. Untuk mengatasinya pemerintah melakukan diskresi dengan tetap memberlakukan aturan lama. Tulisan ini membahas mengenai dampak pelanggaran aturan batas waktu pembentukan peraturan pelaksana dari UU PPMI, sehingga dapat diketahui upaya mengatasi dampak tersebut. Metode penulisan yang digunakan adalah yuridis normatif melalui studi perpustakaan untuk menemukan data sekunder yang dianalisis secara deskriptif kualitatif. Adapun dari pembahasan diketahui bahwa penyebab dilanggarnya batas waktu pembentukan aturan pelaksana adalah adanya kendala teknis dan materi peraturan. Pelanggaran tersebut berdampak tidak terlaksananya sebagian besar ketentuan dalam UU PPMI dan berpengaruh pada proses pelindungan pekerja migran Indonesia (PMI), baik sebelum, selama,
\end{abstract}


maupun sesudah bekerja, seperti masih adanya pembebanan biaya penempatan; adanya penampungan PMI yang menjadi sumber penularan Covid-19; dan maraknya praktik perbudakan PMI pelaut. Oleh karena itu, semua peraturan pelaksana dari UU PPMI perlu segera diundangkan. DPR melalui fungsi pengawasan, baik di Komisi maupun Tim Pengawas PMI, perlu terus mendesak pemerintah membentuk aturan pelaksana dari UU PPMI.

Kata kunci: pelanggaran batas waktu; pembentukan peraturan pelaksana; Pekerja Migran Indonesia; penyebab; dampak

\section{Pendahuluan}

Pada tahun 2017 telah diundangkan UU No. 18 Tahun 2017 tentang Pelindungan Pekerja Migran Indonesia (UU PPMI) pengganti UU sebelumnya yaitu UU No. 39 Tahun 2004 tentang Penempatan dan Perlindungan Tenaga Kerja Indonesia di Luar Negeri (UU PPTKILN). UU PPMI disambut dengan begitu antusias oleh berbagai kalangan terutama Pekerja Migran Indonesia (PMI) dan pihak yang selama ini menaruh perhatian pada PMI. UU PPMI membawa perubahan nomenklatur Tenaga Kerja Indonesia (TKI) menjadi PMI

Dari nama UU terlihat politik hukum pembentukan UU PPMI adalah untuk memberikan pelindungan pada PMI. UU PPMI berusaha mengatur hal-hal yang tidak diatur dalam UU PPTKILN seperti aturan tentang PMI pelaut, pelindungan bagi keluarga PMI, dan Lembaga Pelindungan Satu Atap (LTSA). UU PPMI juga berusaha memperbaiki kekurangan UU PPTKILN antara lain melalui pengaturan penghapusan penampungan; penambahan keterlibatan pemerintah daerah termasuk pemerintah desa; pengaturan secara rinci pembiayaan bagi PMI; sistem jaminan sosial bagi PMI; dan penempatan PMI oleh pemerintah. Serta mengakomodir putusan Mahkamah Konstitusi terkait penghapusan syarat pendidikan minimal bagi PMI yang sebelumnya diatur dalam UU PPTKILN.
3 (tiga) tahun pasca pengundangan UU PPMI seharusnya telah ada peningkatan pelindungan terhadap PMI. Akan tetapi hingga saat ini berita penderitaan PMI masih saja terjadi. Ada PMI yang ditahan karena menjadi pekerja ilegal; PMI pelaut yang diperbudak; proses deportasi yang kurang manusiawi; penyiksaan; dan pembunuhan terhadap PMI. Bahkan pada saat pandemik Covid-19 kondisi menjadi sangat menyulitkan bagi para PMI. Ancaman Pemutusan Hubungan Kerja (PHK) menjadi sangat besar setelah sejumlah negara tujuan PMI mengalami resesi. Praktik penyiksaan terhadap PMI informal ${ }^{1}$ juga dilaporkan meningkat karena pemberi kerja banyak yang tertekan dampak dari pandemi Covid-19. Kebijakan pemerintah yang sempat melakukan moratorium juga meningkatkan kasus PMI ilegal serta adanya penampungan PMI yang menjadi kluster Covid-19. Kondisi ini memperlihatkan perlindungan terhadap PMI belumlah maksimal seperti amanat dari UU PPMI.

Dari hasil pengawasan yang dilakukan Tim Pengawas DPR RI terhadap Pelindungan Pekerja Migran Indonesia (Timwas PMI) diketahui bahwa sejumlah daerah, seperti: Sumatera Utara, Jawa Barat, Jawa Timur dan Sulawesi Selatan belum dapat sepenuhnya menerapkan aturan dalam UU PPMI. ${ }^{2}$ Adapun yang dijadikan alasan umumnya seragam yaitu menunggu adanya peraturan pelaksana dari UU PPMI. Mereka beranggapan selama belum ada aturan pelaksana maka yang berlaku adalah UU PPTKILN beserta aturan pelaksananya. Proses pelindungan yang telah mulai berjalan adalah jaminan sosial bagi PMI yang saat ini telah dikelola oleh BPJS Ketenagakerjaan. Hal ini dikarenakan adanya Peraturan Menteri Ketenagakerjaan

PMI informal adalah PMI yang bekerja pada pengguna perseorangan atau pada sektor domestik (rumah tangga), seperti: baby sitter, housekeeper (Kontan.co.id, "Kemenaker: Sebanyak 48,5\% PMI bekerja di sektor formal di 2019", 11 Februari 2020, https://nasional. kontan.co.id/news/kemenaker-sebanyak-485-pmibekerja-di-sektor-formal-di-2019, diakses tanggal 27 September 2020).

"Laporan Tim Pengawas DPR RI terhadap Pelindungan Pekerja Migran Indonesia”, DPR RI, Jakarta, 2019. 
No. 18 Tahun 2018 tentang Jaminan Sosial Pekerja Migran Indonesia (Permenaker No. 18 Tahun 2018). Sejak Permenaker diundangkan, pemerintah melalui BPJS Ketenagakerjaan telah secara aktif melakukan pelindungan terhadap PMI mulai dari sebelum bekerja, saat bekerja dan setelah bekerja. Konsorsium asuransi saat ini juga telah dihapus semua satu pintu diurus oleh Badan Penyelenggara Jaminan Sosial (BPJS) Ketenagakerjaan.

Kasus terlambatnya bahkan belum adanya aturan pelaksana dari suatu UU, bukan pertama kalinya terjadi. Sejumlah UU telah mengalaminya, seperti UU No. 13 Tahun 2003 tentang Ketenagakerjaan dan UU No. 33 Tahun 2014 tentang Jaminan Produk Halal. Untuk UU Jaminan Produk Halal malah berakibat fatal, tidak saja membuat UU tidak berjalan dengan baik akan tetapi menimbulkan kekosongan hukum dan untuk mengantisipasinya pemerintah terpaksa membuat aturan pelaksana yang isinya bertentangan dengan UU. ${ }^{3}$ Menyadari kondisi ini DPR melalui Komisi IX dan Timwas $\mathrm{PMI}^{4}$ telah secara rutin memanggil pemerintah dalam sejumlah Rapat Dengar Pendapat (RDP) dan Rapat Dengar Pendapat Umum (RDPU) dengan tujuan mendesak pemerintah untuk segera mengundangkan aturan pelaksana tersebut. Namun hingga batas waktu 2 (dua) tahun sesudah UU PPMI diundangkan, baru 3 (tiga) aturan pelaksana yang berhasil diundangkan. Dengan demikian tulisan ini akan membahas tentang apa penyebab terjadinya pelanggaran batas waktu pembuatan peraturan pelaksana dari UU PPMI; bagaimana dampak pelanggaran tersebut dan upaya untuk mengatasinya.

Safari, 24 Mei 2019, "Dinilai Hambat Kewenangan MUI, IHW Judicial Review PP No 31/2019 ke MA”, https:// www.harianterbit.com/nasional/read/106759/DinilaiHambat-Kewenangan-MUI-IHW-Judicial-Review-PP. No-312019-ke-MA, diakses tanggal 27 Juli 2020.

4 Timwas PMI menjalankan fungsi pengawasan DPR sebagaimana diatur dalam Pasal 20A Undang Undang Dasar Negara Republik Indonesia Tahun 1945 dan Pasal 74 UU No. 17 Tahun 2014 tentang Majelis Permusyawaratan Rakyat, Dewan Perwakilan Rakyat, Dewan Perwakilan Daerah, dan Dewan Perwakilan Rakyat Daerah.
Secara umum, tulisan ini bertujuan untuk mengkaji mengenai dampak pelanggaran batas waktu pembuatan peraturan pelaksana dari UU PPMI mengingat masih adanya aturan pelaksana yang belum diundangkan oleh pemerintah dan masih maraknya permasalahan pelindungan terhadap PMI. Secara akademis, diharapkan artikel ini berguna untuk pengembangan ilmu pengetahuan bidang hukum khususnya hukum ketenagakerjaan terkait pelindungan terhadap PMI. Secara praktis, artikel ini diharapkan dapat berguna untuk menjadi bahan pertimbangan dalam perumusan kebijakan mengenai pembentukan peraturan pelaksana dari UU PPMI.

Beberapa tulisan pernah membahas tentang pembentukan peraturan pelaksana dari suatu UU. Tulisan tersebut antara lain dariSukardi dan E. Prajwalita Widiati yang membahas tentang "Pendelegasian Pengaturan oleh UndangUndang kepada Peraturan yang lebih Rendah dan Akibat Hukumnya”. Kajian menganalisis model peraturan pendelegasian dan menurut penulis bentuk pendelegasian yang paling tepat adalah yang rinci dan jelas untuk mencegah diskresi. ${ }^{5}$ Kemudian adapula tulisan dari Fitriani Ahlan Sjarif, tentang "Gaya Perumusan Kalimat Perintah Pembentukan Peraturan yang Menjalankan Delegasi dari Undang-Undang di Indonesia". Tulisan ini membahas terdapat 3 (tiga) UU yang dapat jadi pedoman dalam perumusan perintah pendelegasian dalam suatu UU agar UU dapat berjalan dengan baik. ${ }^{6}$ Sebagian besar tulisan terkait peraturan pelaksana dari UU lebih membahas terkait ketepatan drafting pendelegasian peraturan dalam suatu UU. Sedangkan tulisan ini akan fokus pada masalah pelanggaran jangka waktu pembentukan peraturan pelaksana, dampak, dan kaitannya dengan UU PPMI.

\footnotetext{
Sukardi dan E. Prajwalita Widiati, "Pendelegasian Pengaturan oleh Undang-Undang kepada Peraturan yang Lebih Rendah dan Akibat Hukumnya", Yuridika, Vol. 25, No. 2, 2010.

Fitriani Ahlan Sjarif, "Gaya Perumusan Kalimat Perintah Pembentukan Peraturan yang Menjalankan Delegasi dari Undang-Undang di Indonesia”, Pakuan Law Review, Vol. 3, No. 2, 2017.
} 


\section{Metode Penelitian}

Tulisan ini menggunakan metode penelitian yuridis normatif atau penelitian kepustakaan yaitu penelitian yang dilakukan dengan meneliti bahan-bahan perpustakaan atau data sekunder saja. ${ }^{7}$ Data sekunder terdiri atas bahan hukum primer dan sekunder Bahan hukum primer adalah bahan hukum yang bersifat mengikat, dalam tulisan ini berupa peraturan perundang-undangan antara lain UU PPMI, UU PPTKILN; UU Pelayaran; dan Permenaker No. 18 Tahun 2018. Bahan hukum sekunder merupakan bahan hukum yang menjelaskan tentang bahan hukum primer terdiri atas buku dan jurnal. $^{8}$ Ruang lingkup dari penelitian yuridis normative mencakup asas-asas hukum, sistematika hukum, sinkronisasi vertikal dan horizontal, perbandingan dan sejarah hukum. ${ }^{9}$ Namun dalam tulisan yang digunakan hanya asas hukum terkait pembahasan materi hukum UU PPMI; sistematika hukum sehubungan pembahasan pentingnya posisi pasal yang mengatur pendelegasian peraturan pelaksana dalam UU PPMI; dan sinkronisasi terkait analisa hubungan UU PPMI dengan UU lain yang terkait. Data yang diperoleh dari penelitian ini akan dianalisis secara deskriptif kualitatif. Deskriptif dengan melukiskan suatu keadaan berdasarkan fakta-fakta yang tampak sebagaimana apa adanya. ${ }^{10}$ Dalam tulisan ini yang akan dideskriptifkan adalah proses pembentukan peraturan pelaksana dari UU PPMI. Sedangkan kualitatif dengan memusatkan perhatian pada prisnip-prinsip yang mendasari perwujudan satuan-satuan gejala yang ada dalam kehidupan manusia, atau

Kornelius Benuf dan Muhamad Azhar, "Metodologi Peneltian Hukum sebagai Instrumen Mengurangi Permasalahan Hukum Kontemporer", Jurnal Gema Keadilan, Vol. 7, Edisi 1, Juni 2020, hal. 26.

Ibid.

$9 \quad$ Janpatar Simamora, "Analisa Yuridis terhadap Model Kewenangan Judicial Review di Indonesia”, Mimbar hukum, Vol. 25, No. 3, Oktober 2013, hal. 391.

10 Syahlan, "Rekonstruksi Penataan Peraturan PerundangUndangan Pasca Berlakunya Undang-Undang Nomor 12 Tahun 2011 tentang Pembentukan Peraturan PerundangUndangan", Wacana Hukum, Vol.25 No. 1, Desember 2019, hal. 98 pola-pola yang dianalisis gejala-gejala sosial budaya dengan menggunakan kebudayaan dari masyarakat yang bersangkutan untuk memperoleh gambaran mengenai pola-pola yang berlaku. ${ }^{11}$

\section{Amanah Pembentukan Peraturan Pelaksana dalam UU PPMI}

UU PPMI diundangkan pada tanggal 22 November 2017, terdiri atas 13 Bab dan 91 Pasal yang mengatur mengenai: Ketentuan Umum (Pasal 1- Pasal 3); PMI (Pasal 4- Pasal 6); Pelindungan PMI (Pasal 7- Pasal 37); Layanan Terpadu Satu Atap (Pasal 38); Tugas dan tanggung jawab pemerintah pusat dan daerah (Provinsi, Kabupaten/Kota, dan Desa) (Pasal 39- Pasal 43); Kelembagaan (Pasal 44- Pasal 48); Pelaksana Penempatan Pekerja Migran Indonesia (Pasal 49-Pasal 74); Pembinaan dan pengawasan (Pasal 75- Pasal 76); Penyelesaian perselisihan (Pasal 77); Penyidikan (Pasal 78); Ketentuan Peralihan (Pasal 88); dan Ketentuan Penutup (Pasal - Pasal 91). Pada ketentuan penutup terdapat Pasal 90 UU PPMI mengamanatkan peraturan pelaksana dari UU PPMI harus ditetapkan paling lambat 2 (dua) tahun terhitung semenjak UU ini diundangkan. Artinya, peraturan pelaksana harus sudah ada paling lambat 22 November 2019.

UU PPMI mengamanatkan pembentukan 11 (sebelas) Peraturan Pemerintah (PP). Pemerintah bersepakat menyederhanakan aturan pelaksana tersebut menjadi 3 (tiga) PP yaitu Pelaksanaan Pelindungan PMI; Penempatan PMI oleh Badan; dan Penempatan dan Pelindungan PMI Awak Kapal Niaga dan Awak Kapal. ${ }^{12}$

Selain PP, UU PPMI mengamanatkan pembentukan 12 (dua belas) Peraturan Menteri (Permen) yang kemudian disederhanakan menjadi 5 (lima) Permen yaitu Jaminan Sosial bagi PMI; Penghentian dan Pelarangan

11 Burhan Ashofa, Metode Penelitian Hukum, Jakarta: PT Rineka Cipta, 2013, hal. 20-21.

12 Kemenaker, "Perkembangan Penyusunan Pelaksanaan Undang-Undang Nomor 18 Tahun 2017 tentang Pelindungan Pekerja Migran Indonesia”, Bahan RDP Timwas PMI DPR. Jakarta, 16 Januari 2019. 
Penempatan PMI; Perusahaan Penempatan PMI (P3MI); Sanksi Administratif; dan Pelaksanaan Penempatan PMI oleh P3MI, Penempatan Untuk Kepentingan Perusahan Sendiri (UKPS), dan PMI Perorangan. ${ }^{13}$
PMI. Pemerintah tetap akan mempertahankan dan tidak akan menyederhanakan 2 (dua) Perpres dan 3 (tiga) Perka ini. ${ }^{14}$ Adapun detail amanat aturan pelaksana dalam UU PPMI dapat dilihat pada tabel 1 .

Tabel 1. Rencana Penyederhanaan Aturan Pelaksana UU PPMI

\begin{tabular}{|c|c|c|c|}
\hline No & Rencana Penyederhanaan & $\mathrm{Bab}$ & $\begin{array}{l}\text { Pasal Sumber Aturan } \\
\text { Pelaksana }\end{array}$ \\
\hline \multirow[t]{5}{*}{1.} & Peraturan Pemerintah tentang Pelindungan Pekerja Migran Indonesia. & $\mathrm{Bab} 3$ & $\begin{array}{l}\text { Pasal 20, Pasal 23, Pasal } \\
\text { 28, Pasal } 36 .\end{array}$ \\
\hline & & Bab 4 & Pasal 38 ayat (4) \\
\hline & & Bab 5 & Pasal 43 \\
\hline & & $\mathrm{Bab} 7$ & Pasal 52 ayat (2). \\
\hline & & Bab 8 & $\begin{array}{l}\text { Pasal } 75 \text { ayat (3) dan Pasal } \\
76 \text { ayat (3) }\end{array}$ \\
\hline 2. & $\begin{array}{l}\text { Peraturan Pemerintah No. } 10 \text { Tahun } 2020 \text { tentang Tata Cara Penempatan } \\
\text { Pekerja Migran Indonesia Oleh Badan Pelindungan Pekerja Migran Indonesia } \\
\text { (telah diundangkan } 31 \text { Januari 2020) }\end{array}$ & Bab 7 & Pasal 50 ayat (2) \\
\hline 3. & $\begin{array}{l}\text { Peraturan Pemerintah tentang Penempatan dan Pelindungan Pelaut Awak Kapal } \\
\text { dan Pelaut Perikanan. }\end{array}$ & Bab 7 & Pasal 64 \\
\hline 4. & Peraturan Presiden tentang Tugas dan Wewenang Atase Ketenagakerjaan. & Bab 3 & Pasal 22 ayat (4) \\
\hline 5. & $\begin{array}{l}\text { Peraturan Presiden No. } 90 \text { Tahun } 2019 \text { tentang Badan Pelindungan Pekerja } \\
\text { Migran Indonesia (telah diundangkan } 30 \text { Desember 2019) }\end{array}$ & Bab 6 & Pasal 48 \\
\hline 6. & $\begin{array}{l}\text { Peraturan Menteri Ketenagakerjaan No. } 18 \text { Tahun } 2018 \text { tentang Jaminan Sosial bagi } \\
\text { Pekerja Migran Indonesia (telah diundangkan } 10 \text { Desember 2018) }\end{array}$ & Bab 3 & Pasal 29 ayat (5) \\
\hline 7. & $\begin{array}{l}\text { Peraturan Menteri Ketenagakerjaan No. } 17 \text { Tahun } 2019 \text { tentang Penghentian dan } \\
\text { Pelarangan Penempatan Pekerja Migran Indonesia (telah diundangkan 1 Oktober 2019) }\end{array}$ & Bab 3 & Pasal 32 ayat (4) \\
\hline \multirow[t]{2}{*}{8.} & \multirow[t]{2}{*}{ Peraturan Menteri tentang Perusahaan Penempatan Pekerja Migran Indonesia. } & Bab 3 & Pasal 37 ayat $(2)$ \\
\hline & & $\mathrm{Bab} 7$ & $\begin{array}{l}\text { Pasal } 51 \text { ayat (3), Pasal } 53 \\
\text { ayat (4), Pasal } 54 \text { ayat (3), } \\
\text { Pasal } 55 \text { ayat (3), Pasal } 57 \\
\text { ayat (5) dan Pasal } 74 \text { ayat (2) }\end{array}$ \\
\hline 9. & $\begin{array}{l}\text { Peraturan Menteri Ketenagakerjaan No. } 7 \text { Tahun } 2020 \text { tentang Tata Cara Pengenaan } \\
\text { Sanksi Administratif dalam Pelaksanaan Penempatan dan Pelindungan Pekerja } \\
\text { Migran Indonesia (telah diundangkan } 20 \text { April 2020) }\end{array}$ & Bab 3 & Pasal 37 ayat (2) \\
\hline 10. & $\begin{array}{l}\text { Peraturan Menteri Ketenagakerjaan No. } 9 \text { Tahun } 2019 \text { tentang Tata Cara } \\
\text { Penempatan Pekerja Migran Indonesia (telah diundangkan } 28 \text { Juni 2019) }\end{array}$ & Bab 6 & $\begin{array}{l}\text { Pasal 60, Pasal } 61 \text { ayat (3), } \\
\text { Pasal } 63 \text { ayat (4) }\end{array}$ \\
\hline 11. & $\begin{array}{l}\text { Peraturan Kepala Badan No. } 9 \text { Tahun } 2020 \text { tentang Pembebasan Biaya } \\
\text { Penempatan Pekerja Migran Indonesia (telah diundangkan } 14 \text { Juli 2020) }\end{array}$ & Bab 3 & Pasal 30 \\
\hline 12. & Peraturan Kepala Badan tentang Standar Perjanjian Kerja, dan & Bab 3 & Pasal 15 ayat (3) \\
\hline 13. & Peraturan Kepala Badan proses yang dipersyaratkan bagi Calon Pekerja Migran Indonesia. & Bab 3 & Pasal 12 ayat (2) \\
\hline
\end{tabular}

Sumber: diolah dari berbagai sumber ${ }^{15}$

UU PPMI juga mengamanatkan pembentukan 2 (dua) Peraturan Presiden (Perpres) yaitu terkait pembentukan badan dan wewenang atase ketenagakerjaan. Terakhir, UU PMI juga mengamanatkan pembentukan 3 (tiga) Peraturan Kepala Badan (Perka), yaitu terkait biaya penempatan, Standar Perjanjian Kerja, dan proses yang dipersyaratkan bagi Calon

13 Ibid.
Dari 13 rencana aturan pelaksanaan yang akan dibentuk, hanya 3 (tiga) aturan pelaksana

\footnotetext{
$14 \quad$ Ibid.

15 BNP2TKI, "Progress Pelaksanaan UU No 18 Tahun 2017 Tentang Pelindungan Pekerja Migran Indonesia”, Bahan RDP Timwas PMI. Jakarta, 16 Januari 2019; dan Kemenaker, "Perkembangan Penyusunan Pelaksanaan Undang-Undang Nomor 18 Tahun 2017 tentang Pelindungan Pekerja Migran Indonesia", Bahan RDP Timwas PMI DPR. Jakarta, 16 Januari 2019.
} 
yang berhasil diundangkan tepat waktu yaitu Permen No. 18 Tahun 2018 tentang Jaminan Sosial bagi Pekerja Migran Indonesia, Permen Ketenagakerjaan No. 9 Tahun 2019 tentang Tata Cara Penempatan Pekerja Migran Indonesia dan Permen Ketenagakerjaan No. 17 Tahun 2019 tentang Penghentian dan Pelarangan Penempatan Pekerja Migran Indonesia. Tepat waktu artinya sebelum jangka waktu 2 (dua) tahun terhitung semenjak UU PPMI diundangkan sesuai ketentuan Pasal 90 UU PPMI. Kemudian hingga tulisan ini dibuat ada 4 (empat) aturan yang telah terbit namun sesudah 22 November 2019, sedangkan sisanya sebanyak 6 aturan pelaksana belumlah terbit. Peraturan pelaksana ini merupakan muatan dari Bab 3 - Bab 8 dari 13 Bab yang terdapat dalam UU PPMI.

Bab 3 - Bab 8 merupakan inti dari UU PPMI karena memuat banyak hal baru yang tidak diatur dalam UU PPTKILN. Aturan baru tersebut antara lain perluasan lingkup PMI tidak hanya yang bekerja di darat namun juga program jaminan sosial bagi PMI dan keluarganya (Pasal 29); pembebasan biaya penempatan bagi PMI (Pasal 30 ayat (1)); pemberian pelindungan hukum, sosial dan ekonomi pada PMI dan keluarganya (Pasal 31- Pasal 36); perluasan hak PMI seperti hak atas komunikasi, berserikat, dan menguasai dokumen perjalanan (Pasal 6 ayat (1)); memperluas peran atase ketenagakerjaan (Pasal 22); perluasan peran pelindungan dari pemerintah daerah termasuk pemerintah desa (Bab 5). Selain itu bab-bab ini juga mengganti atau memperbaiki aturan yang telah ada sebelumnya, seperti dihapuskannya syarat pendidikan minimal bagi PMI sesuai putusan Mahkamah Konstitusi (Pasal 5); menghapus aturan penampungan bagi PMI; mempermudah proses perpanjangan perjanjian kerja dengan tidak harus kembali ke Indonesia (Pasal 17); mengurangi peran pelindungan perusahaan penempatan PMI; memperjelas tanggung jawab kantor cabang dari perusahaan penempatan (Pasal 53). Perbedaan materi UU PPMI dengan UU PPTKILN dapat terlihat dari tabel 2.

Tabel 2. Perbandingan Materi UU PPMI dengan UU PPTKILN

\begin{tabular}{|c|c|c|c|}
\hline No & Materi & UU PPTKILN & UU PPMI \\
\hline 1. & Area kerja PMI & Darat & Darat dan lautan \\
\hline 2. & Penampungan & Diatur & Tidak Diatur \\
\hline 3. & Biaya Penempatan & Diatur & Dihapuskan \\
\hline 4. & Peran Pemerintah Desa & Tidak Diatur & Diatur \\
\hline 5. & Atase Ketenagakerjaan & Diatur secara terbatas & Diperkuat \\
\hline 6. & LTSA & Tidak Diatur & Diatur \\
\hline 7. & Pelindungan hukum, sosial dan ekonomi & Diatur secara terbatas & Diperkuat \\
\hline 8. & Hak atas komunikasi dan hak berserikat & Tidak diatur & Diatur \\
\hline 9. & Perjanjian Kerja & Diatur secara rinci & Sepakat para pihak \\
\hline 10. & Jaminan Sosial & Tidak diatur & Diatur \\
\hline 11. & Badan sebagai operator & Tidak tegas diatur & Diatur secara tegas \\
\hline 12. & Pelindungan bagi keluarga PMI & Tidak diatur & Diatur \\
\hline 13. & Peran Pelindungan dari Perusahaan Penempatan PMI & Besar & Diminimalisasi \\
\hline
\end{tabular}

Sumber: diolah dari berbagai sumber ${ }^{16}$

laut dengan dimasukkannya pelaut awak kapal dan pelaut perikanan sebagai PMI (Pasal 4 ayat (1)); penambahan hak keluarga PMI (Pasal 6 ayat (3)); pelayanan terpadu bagi PMI melalui Layanan Terpadu Satu Atap (LTSA) (Bab 4);
16 BNP2TKI, "Progress Pelaksanaan UU No 18 Tahun 2017 Tentang Pelindungan Pekerja Migran Indonesia”, Bahan RDP Timwas PMI DPR. Jakarta, 16 Januari 2019; "Isu Krusial Pada Tata Kelola Pekerja Migran", Hasil Konsinyering Pembahasan RUU PPMI, Kopo, 16 April 2017; dan diolah sendiri dengan membandingkan materi UU PPTKILN dengan UU PPMI. 
Ketiadaan aturan pelaksana merupakan salah satu faktor yang mempengaruhi proses penegakan hukum menurut Soerjono Soekanto. ${ }^{17}$ Apalagi terkait UU PPMI, peraturan pelaksana menyangkut substansi penting dari pergantian UU dari UU PPTKILN menjadi UU PPMI. Sehingga wajar apabila dari hasil pengawasan yang dilakukan oleh Timwas PMI dalam priode 2018-2019, sejumlah pemerintah daerah menyatakan bahwa mereka masih menggunakan aturan yang lama yaitu UU PPTKILN beserta aturan pelaksananya. Daerah tersebut antara lain Jawa Barat ${ }^{18}$, Jawa Tengah $^{19}$, Sumatera Utara $^{20}$ dan Sulawesi Selatan ${ }^{21}$. Adapun aturan dalam UU PPMI yang berjalan hingga saat ini adalah aturan tentang jaminan sosial bagi pekerja migran. Itupun pada awalnya penerimaan klaim masih sangat terbatas karena masih belum up datenya data PMI. ${ }^{22}$

Penggunaan aturan lama yaitu UU PPTKILN dan peraturan pelaksananya oleh sejumlah pemerintah daerah dalam rangka mengisi kekosongan hukum karena belum hadirnya aturan pelaksana memang dapat saja dilakukan. Berdasakan Pasal 1 angka 9 UU No. 30 Tahun 2014 tentang Administrasi Pemerintahan (UU Administrasi Pemerintahan), pemerintah memiliki kewenangan melakukan diskresi untuk mengatasi persoalan yang dihadapi dalam penyelenggaraan pemerintahan dalam hal peraturan perundang-undangan yang memberikan pilihan, tidak mengatur, tidak lengkap atau tidak jelas, dan/atau adanya stagnasi pemerintahan. Hanya saja pejabat pemerintahan yangmenggunakandiskresiharus memperhatikan berbagai ketentuan yang dipersyaratkan dalam UU Administrasi Pemerintahan, seperti harus

\footnotetext{
18 Hasil Kunjungan Tim Pengawas DPR RI Provinsi Jawa Barat dilaksanakan pada tanggal 4-6 Oktober 2018. hal. 33.

19 Hasil Kunjungan Tim Pengawas DPR RI ke Provinsi Jawa Tengah, 2 Juli 2019.

20 Hasil Kunjungan Tim Pengawas DPR RI ke Provinsi Sumatera Utara dilaksanakan pada tanggal 25-27 April 2019. hal 43 .

21 Hasil Kunjungan Lapangan Tim Pengawas DPR RI ke Provinsi Sulawesi Selatan dilaksanakan pada tanggal 24 s.d. 26 Januari 2019. hal. 42.

22 Ibid.
}

sesuai tujuan dan tidak menimbulkan konflik kepentingan (Pasal 24). Permasalahannya pada beberapa kasus ditemukan keterlibatan aparat dalam permasalahan PMI seperti: membantu praktek percaloan ${ }^{23}$ dan menjadi pelaku human trafficking. ${ }^{24}$

\section{Penyebab terjadinya Pelanggaran Batas Waktu Pembentukan Peraturan Pelaksana dari UU PPMI}

Faktor penyebab terjadinya pelanggaran bataswaktu pembentukan peraturan perundangundangan ada dua yaitu faktor teknis dan substansi. Pembahasan peraturan pelaksana UU PPPMI juga mengalami kedua kendala ini. Kendala teknis pertama adalah terkait banyaknya aturan pelaksana yang didelegasikan oleh UU PPMI. Setidaknya terdapat 28 Pasal pendelegasian yang mana 11 Pasal mengamanatkan PP; 2 Pasal mengamanatkan Peraturan Presiden; 12 Pasal mengamanatkan Permen dan 3 Pasal mengamanatkan Peraturan Kepala Badan. Pemerintah kemudian memutuskan untuk melakukan perampingan dengan menggabungkan sejumlah materi yang sama dalam satu aturan sehingga akhirnya diciutkan menjadi 13 aturan pelaksana. Untuk menyederhanakan peraturan ini tentunya pemerintah membutuhkan waktu. Proses perampingan peraturan ini dikenal juga dengan simplifikasi peraturan yang dilakukan dengan cara mengendalikan pembentukan regulasi dengan membatasi seminimal mungkin terbitnya peraturan baru. ${ }^{25}$ Simplifikasi tidak hanya dapat lakukan terhadap peraturan yang sudah ada (existing regulation) namun juga yang akan ada (future regulation), ${ }^{26}$ seperti: terkait

23 Made Ngurah Demi Andayana, "Penyimpangan Kebijakan Pengiriman TKI Ke Luar Negeri”, Journal of Management (SME's), Vol.9 No.2, 2019, hal. 254.

24 Siti Muflichah dan Rahadi Wasi Bintoro, "Trafficking: Suatu Studi Tentang Perdagangan Perempuan Dari Aspek Sosial, Budaya Dan Ekonomi Di Kabupaten Banyumas", Jurnal Dinamika Hukum, Vol.9, No. 1, Januari 2009, hal. 129

25 Diani Sadiawati dkk., Kajian Reformasi Regulasi di Indonesia: Pokok Permasalahan dan Strategi Penanganannya, Jakarta: PSHK, 2019, hal. 68.

26 Ibid., hal. 8. 
proses pembentukan aturan pelaksana dari UU PPMI. Hanya saja dalam melakukan simplifikasi dibutuhkan proses inventarisasi, dan identifikasi dengan melibatkan pemangku kepentingan terkait. ${ }^{27}$ Jika pemangku kepentingannya banyak tentu akan memakan waktu hal inilah yang dialami oleh peraturan pelaksana dari UU PPMI.

Kendala teknis berikutnyaadalahbanyaknya instansi/kementerian yang terlibat antara lain: Kementerian Ketenagakerjaan sebagai regulator pelindungan PMI; Kementerian Dalam Negeri dalam penyelenggaraan LTSA; Kementerian Luar Negeri terkait keberadaan Perwakilan dan Atase Ketenagakerjaan serta pelindungan PMI di luar negeri; Kementerian Koperasi dan Usaha Kecil dan Menegah terkait pemanfaatan Kredit Usaha Rakyat (KUR); Kementerian Desa, Pembangunan Daerah Tertinggal dan Transmigrasi terkait peran tenaga pendampingan desa; Direktorat Jenderal Imigrasi sehubungan pembuatan paspor PMI; Kementerian Sosial menyangkut pemulangan PMI bermasalah; Kementerian Kesehatan terkait tes kesehatan bagi calon PMI; Kementerian Pemberdayaan Perempuan dan Anak sehubungan pelindungan bagi PMI wanita dan anak PMI; Kementerian Perhubungan sehubungan keberangkatan PMI dan PMI Pelaut; Kementerian Kelautan dan Perikanan menyangkut PMI pelaut perikanan; Kementerian Pendidikan terkait pendidikan dan pelatihan vokasi; Kemenkopolhukam sebagai koordinator penanganan PMI bermasalah; Polri dalam menangani Tindak Pidana Perdagangan Orang; Kementerian Agama terkait penerbitan rekomendasi paspor umrah; BPJS Ketenagakerjaan dalam pemberian jaminan sosial; Badan Pelindungan Pekerja Migran Indonesia (BP2MI) sebagai operator pelindungan PMI. Banyaknya instasi yang terlibat tentunya jadi permasalahan tersendiri dalam proses pembentukan peraturan pelaksana karena masing-masing instansi memiliki kepentingan dalam proses pembahasan.

27 Ibid., hal. 10.
Proses pembentukan UU dapat dijadikan sebagai pembanding. Pada saat proses pembahasan PMI ego sektoral dan tarik menarik kepentingan antara instansi yang terlibat sangat terlihat jelas. ${ }^{28}$ Kondisi ini menjadi salah satu faktor terhambatnya proses pembahasan dari UU PPMI. Proses pembuatan UU ini telah dimulai semenjak tahun 2009 dan baru berhasil diundangkan pada tahun 2017. Proses pengundangan baru selesai dilakukan setelah sejumlah pasal yang spesifik dihapuskan dari muatan UU, misalnya berkaitan dengan pembentukan dan kewenangan badan, dan dewan pengawas. Penghapusan ini menjadi salah satu penyebab banyaknya pendelegasian aturan. Pendelegasian aturan dimaksudkan agar pemerintah dapat membahasnya secara internal.

Kendala teknis yang ketiga adalah terbatasnya sarana dan prasarana daerah dalam mendukung kebijakan terkait LTSA. UU PPMI mengamanatkan pendirian LTSA untuk menjadikan pelayanan pelindungan dan penempatan terhadap PMI dapat terintegrasi dengan baik. Oleh karena itu setidaknya dibutuhkan infrastruktur gedung untuk mendukung pelayanan dari berbagai instansi yang terintegrasi tersebut. Peralatan yang memadai juga diperlukan untuk mendukung pendidikan dan pelatihan kerja bagi PMI. Fasilitas pelayanan kesehatan yang menunjang juga perlu ada untuk memudahkan tes kesehatan terhadap PMI. Setidaknya ada 2 hal yang dibutuhkan untuk pendirian LTSA yaitu anggaran dan sumber daya manusia. Permasalahannya tidak semua daerah memilikinya. Hal ini juga menjadi pertimbangan dari pemerintah dalam membentuk aturan pelaksana terutama terkait pendirian LTSA.

Secara Substansi, yang menjadi kendala adalah sejumlah pasal dalam UU PPMI menimbulkan tumpang tindih (overlapping) kewenangan, seperti aturan yang mengatur tentang pemberdayaan sosial dan ekonomi purna PMI menjadi tugas 3 instansi yaitu Menaker (Pasal 45), Kepala Badan (Pasal 47) dan

\footnotetext{
28 "Laporan Akhir Pelaksanaan Tugas Timwas DPR RI terhadap Perlindungan Tenaga Kerja Indonesia”, DPR RI, Jakarta, September 2014, hal. 171.
} 
Pemerintah Desa (Pasal 42). Kemudian pasal pemulangan PMI dalam hal terjadi peperangan, bencana alam, wabah penyakit, deportasi, dan PMI Bermasalah menjadi tanggung jawab pemerintah pusat (Pasal 39) akan tetapi dalam Pasal 40 dan Pasal 41 menjadi tanggung jawab pemerintah daerah. ${ }^{29}$ Pengaturan tugas yang sama namun menjadi tanggung jawab beberapa instansi berpotensi menimbulkan permasalahan terkait pengelolaan anggaran karena masingmasing instansi akan mengklaim memiliki kewenangan untuk mengajukan anggaran. ${ }^{30}$ Namun apabila terjadi permasalahan para pihak ini justru akan saling lepas tanggung jawab. Ketidakjelasan pengaturan menurut Soerjono Soekanto memang berpotensi mengganggu penegakan hukum dari sebuah UU. ${ }^{31}$

Permasalahan substansi lainnya adalah terdapatnya overlapping peraturan yang berdampak pada pembahasan aturan pelaksana. Aturan pertama adalah terkait pembentukan LTSA. Saat ini di sejumlah daerah telah berdiri pelayanan terpadu dalam bentuk Mall Pelayanan Publik yang berdiri berdasarkan Permendagri No. 138 Tahun 2017 tentang Penyelenggaraan Pelayanan Terpadu Satu Pintu Daerah (Permendagri No. 138 Tahun 2017). Dalam proses pembahasan menjadi kendala apakah LTSA dapat diintegrasikan dalam Mall Pelayanan Publik atau tidak. Menurut Kemendagri, pengintegrasian dapat saja dilakukan dasar hukumnya adalah Pasal 33 Permendagri No. 138 Tahun 2017. Pada pasal tersebut dibuka ketentuan bahwa pengintegrasian pelayanan dengan dapat dilakukan dengan Dinas Kependudukan dan Catatan Sipil, Badan Penyelenggara Jaminan Sosial, Direktorat Jenderal Pajak, Kemenkumham, BPN, Perbankan, Asuransi dan Pihak lain yang terkait dengan peningkatan Pelayanan Publik. LTSA PMI dapat masuk sebagai pihak lain dalam penyelenggaraan pelayanan terpadu tersebut. Permasalahannya adalah bentuk pelayanannya

\footnotetext{
29 BNP2TKI, "Progress Pelaksanaan UU No. 18 Tahun 2017 tentang Pelindungan Pekerja Migran Indonesia", Hasil RDP Timwas PMI DPR, Jakarta, 16 Januari 2019.

$30 \quad$ Ibid

31 Soerjono Soekanto, Op.cit., hal. 18.
}

berbeda, pelayanan publik tersebut satu pintu sedang pelayanan PMI satu atap.

Pelayanan satu pintu dan satu atap pada dasarnya sama-sama merupakan merupakan bentuk pelayanan terpadu yang diselenggarakan pada satu tempat. Hanya saja pada pelayanan satu atap terdapat berbagai jenis pelayanan yang dilayani pada beberapa loket, sedangkan pelayanan satu pintu beberapa pelayanan yang diberikan memiliki keterkaitan sehingga dapat dilayani dengan satu loket. ${ }^{32}$ Kepala pelayanan satu atap tidak memiliki kewenangan administrasi maupun teknis, berbeda dengan kepala pelayanan satu pintu yang memiliki kewenangan tersebut..$^{33}$

Tumpang tindih peraturan juga terjadi terkait pembahasan peraturan pelaksana PMI Pelaut. UU PPMI membagi PMI pelaut atas dua yaitu PMI pelaut awak kapal dan PMI pelaut perikanan. Terkait PMI pelaut awak kapal selama ini telah terjadi tumpang tindih kewenangan antara Kementerian Perhubungan dengan Kementerian Ketenagakerjaan terkait izin perusahaan perekrutan dan penempatan awak kapal pelaut. Menurut PP No. 7 Tahun 2000 tentang Kepelautan, penempatan pelaut berdasarkan Keputusan Menteri Ketenagakerjaan setelah mendengar pendapat Menteri Perhubungan. Sedangkan menurut UU PPTKILN, surat izin perusahaan dikeluarkan oleh Kementerian Ketenagakerjaan. Namun menurut Permen Perhubungan No. 84 tahun 2013 tentang Perekrutan dan Penempatan Awak Kapal, terkait aturan perizinan perekrutan dan penempatan awak kapal keluar negeri adalah kewenangan menteri perhubungan. ${ }^{34}$ Apabila terjadi permasalahan yang menimpa PMI pelaut maka sering kali

\footnotetext{
32 Lia Melanie Ginting, Elisa Susanti, dan Asep Sumaryana, "Implementasi Pelayanan Terpadu Satu Pintu NonPerizinan di Ukur dari Kepuasan Masyarakat dengan Menggunakan Indeks Kepuasan Masyarakat”, Responsive, Vol. 1 No. 2 Desember 2018, hal. 46.

33 Ibid

34 Imam Syafii, 16 Desember 2020, "PP Penempatan dan Pelindungan Pelaut Indonesia di Luar Negeri Harus Mampu Mengatasi Tumpang Tindih Regulasi”, https:// ppi.or.id/editorial/pp-penempatan-dan-pelindunganpelaut-indonesia-di-luar-negeri-harus-mampu-mengatasitumpang-tindih-regulasi/, diakses tanggal 2 Agustus 2020.
} 
antara Kementerian Ketenagakerjaan dan Kementerian Perhubungan saling lempar tanggung jawab. ${ }^{35}$

Belum lagi permasalahan terkait PMI pelaut perikanan. PMI pelaut perikanan kurang terlindungi karena bekerja di kapal ikan berbendera asing secara individual atau mandiri. Kondisi ini diperburuk dengan tidak adanya data pasti terkait PMI sehingga membuat sulitnya pemantauan dan pengawasan. Selain itu terdapat tumpang tindih kewenangan dalam penerbitan izin keagenan perusahaan perekrutan dan penempatan awak kapal ikan (manning agency). Saat ini, ada 3 (tiga) jenis izin penempatan ABK Indonesia di kapal ikan asing: Pertama, manning agency yang memiliki Surat Izin Usaha Perekrutan dan Penempatan Awak Kapal (SIUPPAK) dari Kementerian Perhubungan; Kedua, manning agency yang memiliki Surat Izin Perusahaan Penempatan Pekerja Migran Indonesia (SIP3MI) dari Kementerian Ketenagakerjaan dan Surat Izin Perekrutan Pekerja Migran Indonesia (SIP2MI) dari BP2MI, Ketiga, manning agency yang memiliki Surat Izin Usaha Perdagangan (SIUP) dari Kementerian Perdagangan atau Dinas Perdagangan pada Pemerintah Daerah. ${ }^{36}$ Permasalahannya jika terjadi masalah dengan PMI, instansi pemberi izin justru lepas tangan.

\section{Dampak Pelanggaran Batas Waktu Pembentukan Peraturan Pelaksana dari UU PPMI}

Berdasarkan siklus kerja PMI terdapat 3 (tiga) tahapan yang dilalui PMI yaitu sebelum bekerja, selama bekerja dan setelah bekerja. Dampak dari pelanggaran batas waktu pembentukan peraturan pelaksana UU PMI akan dianalisis berdasarkan 3 (tiga) siklus kerja PMI tersebut.

\footnotetext{
$35 \quad$ Fis Purwangka, "Model Pengelolaan Keselamatan Kerja Nelayan di Pelabuhanratu Kabupaten Sukabumi”, Jurnal IPTEKS PSP, Vol.5 No.9, April 2018, hal. 9.

36 Fadilla Octaviani, "Perbaikan Tata Kelola Pelindungan Abk Indonesia Di Kapal Ikan Asing, Indonesia Ocean Justice Initiative”, Policy Brief 3, Juni 2020.
}

\section{A. Sebelum Bekerja}

UU PPMI mengatur pentingnya pendidikan dan pelatihan kerja bagi para PMI. Hal ini menjadi bagian dari hak PMI, pelindungan PMI sebelum bekerja, pelindungan sosial PMI yang menjadi tanggung jawab pemerintah pusat dan daerah. Hanya saja PP tentang Pelindungan Pekerja Migran Indonesia yang hingga saat ini masih belum rampung. Harusnya terkait pendidikan dan pelatihan bagi PMI terdapat dalam PP tersebut. Akibatnya berdasarkan data BP2MI dari kurun waktu 2017-1019 jumlah PMI yang bekerja pada sektor informal selalu mendominasi. Latar pendidikan PMI juga didominasi oleh lulusan SMP sederajat. ${ }^{37}$

Pembentuk UU PPMI sebetulnya ingin meningkatkan pendidikan dan pelatihan bagi PMI sehingga PMI yang ditempatkan nantinya akan didominasi oleh PMI formal yaitu PMI yang bekerja di luar sektor rumah tangga dan perseorangan. Jadi lebih pada PMI terampil sehingga proses pelindungannyapun juga lebih mudah. Padahal sebetulnya jumlah pengangguran di Indonesia di dominasi oleh lulusan vokasi setingkat SMU/ SMK sederajat. Sehingga ada kecenderungan tenaga kerja vokasi tidak terserap pasar kerja di luar negeri. Kondisi ini dapat disebabkan oleh adanya permasalahan kurikulum pendidikan vokasi yang tidak sesuai dengan kebutuhan luar negeri; kurangnya minat lulusan vokasi untuk menjadi PMI atau bisa juga akibat kurangnya informasi lowongan pekerjaan. Oleh karena itu untuk meningkatkan jumlah PMI sektor formal disamping dengan membentuk BLK luar negeri pemerintah juga perlu memperbaharui kurikulum pendidikan vokasi agar sejalan dengan kebutuhan pasar kerja luar negeri. Selain itu aturan terkait informasi lowongan pekerjaan juga perlu di perkuat. Belum adanya peraturan pelaksana terkait pelindungan PMI yang di dalamnya mengatur informasi kerja, pendidikan dan pelatihan vokasi bagi calon PMI juga berpengaruh pada daya tampung PMI lulusan SMK sederajat.

\footnotetext{
37 BP2PMI, Data Penempatan dan Pelindungan Pekerja Migran Indonesia Tahun 2019, Jakarta: Pusat Penelitian Pengembangan dan Informasi BP2PMI, 2020.
} 
Pasal 30 UU PPMI mengatur bahwa kepada PMI tidak dapat dikenakan biaya penempatan dan ketentuan lebih lanjut tentang biaya penempatan diatur oleh kepala badan. Pada 12 Juli 2020, Kepala Badan telah menerbitkan Peraturan Badan Pelindungan PMI No. 9 Tahun 2020 tentang Pembebasan Biaya Penempatan PMI. Peraturan ini memberikan waktu selama 6 bulan untuk penyesuaian. Hingga saat ini peraturan kepala badan tersebut masih dalam tahap penyesuaian sehingga sebagian PMI masih menanggung besarnya biaya penempatan. Seperti PMI Hongkong, yang masih dipungut biaya penempatan. Biaya tersebut nantinya akan dipotong dari gaji PMI dengan jumlah potongan yang cukup besar hingga mencapai 90\% dari 4-6 bulan gaji pertama yang harus diterima PMI. ${ }^{38}$ Pemotongan dilakukan oleh PPTKIS dan agensi di Hongkong. Adapuan dasar dari biaya penempatan tersebut adalah Kemenakertrans No. 98 tahun 2012 tentang Komponen dan Besarnya Biaya Penempatan Calon Tenaga Kerja Indonesia Sektor domestik Negara Tujuan Hong Kong SAR, yang mengatur bahwa TKI Hongkong dibebankan biaya penempatan sebesar Rp. 14.780.400. ${ }^{39}$ Kepmenaker ini harusnya tidak berlaku karena bertentangan dengan UU PPMI dan berdasarkan Pasal 89 UU PPMI harusnya tidak berlaku lagi. ${ }^{40}$

Peraturan Badan Pelindungan PMI No. 9 Tahun 2020 tentang Pembebasan Biaya Penempatan PMI memiliki kelemahan karena hanya berlaku mengikat bagi PMI yang diberangkatkan oleh Badan. Sedangkan bagi PMI yang diberangkatkan P3MI, badan hanya

38 Ridwan Wahyudi, 12 Februari 2020, "Pelindungan Komprehensif bagi Pekerja Migran Indonesia di Hong Kong”, https://buruhmigran.or.id/2020/02/12/ pelindungan-komprehensif-bagi-pekerja-migranindonesia-di-hong-kong/, diakses tanggal 2 Agustus 2020.

39 Donna Savira Larasati, "Peran Pemerintah Indonesia dalam Melindungi Hak TKI dari Praktik Underpayment di Hongkong", Journal of International Relations, Vol. 4, No. 3, 2018, hal. 360-366.

40 Pasal 89 UU PPMI mengatur pencabutan UU PPTKILN dan menyatakan bahwa peraturan pelaksana UU PPTKILN masih tetap berlaku selama tidak bertentangan dengan materi UU PPMI. bisa memberikan rekomendasi pada menteri. Sehingga masih diperlukan aturan biaya penempatan bagi PMI yang diberangkatkan oleh P3MI.

UU PPTKILN mengatur mengenai masa tunggu di penampungan sebelum PMI di tempatkan. Aturan tersebut dihapus oleh UU PPMI, melalui aturan terkait LTSA, kemudahan dan pengawasan proses pemberangkatan. Penghapusan penampungan karena pembentuk UU menilai bahwa banyak masalah yang timbul dengan adanya penampungan, seperti: maraknya praktek PMI ilegal, pelanggaran prosedur penempatan, membengkaknya biaya penempatan yang harus ditanggung PMI. PMI juga sering mengalami kekerasan dan eksploitasi di penampungan. ${ }^{41}$ Namun saat ini penampungan PMI tetap ada, seperti baru-baru ditemukan adaya penampungan PMI ilegal di Cilengsi Bogor, dan Jatiasih Bekasi ${ }^{42}$ sebelumnya juga ada penampungan PMI ilegal di Pondok Kopi (2019). Maraknya kasus penampungan PMI ilegal memperlihatkan bahwa hingga saat ini penampungan PMI masih tetap ada.

Penampungan PMI ilegal mengarah pada tindak Pidana Pergagangan Orang (TPPO). Penampungan PMI ditengah merebaknya Covid-19 juga berbahaya karena dapat menjadi sumber penularan Covid-19. Kemenaker sebetulnya semenjak 20 Maret 2020 telah melakukan moratorium pengiriman PMI ke luar negeri melalui Kepmenaker No. 151 Tahun 2020 tentang Penghentian Sementara Penempatan Pekerja Migran Indonesia, ${ }^{43}$ sebagai upaya melindungi PMI dari Pandemi Covid-19. Akan tetapi moratorium justru berdampak merebaknya pengiriman PMI secara ilegal sehingga akhirnya kebijakan ini dicabut.

\footnotetext{
${ }^{41}$ Syamsuddin \& Gunadi Setyo Utomo, "Permasalahan Buruh Migran Indonesia pada Sektor Publik", Jurnal PKS, Vol 15 No 3 September 2016, hal.258.

42 Infopena.com, 4 mei 2020, "GARUDA Sulteng Apresiasi Penggerebekan Penampungan Calon Pekerja Migran Oleh BP2MI", https:/www.infopena.com/blog/garudasulteng-apresiasi-penggerebekan-penampungan-calonpekerja-migran-oleh-bp2mi/, diakses tanggal 2 Agustus 2020.

43 Pada Juli 2020, moratorium ini telah dicabut oleh Kementerian Ketenagakerjaan.
} 
Pembangunan LTSA pada beberapa daerah sudah mulai berjalan antara lain di Kalimantan Barat, Jawa Barat dan Jawa Timur. Pendirian LTSA diutamakan di daerah yang merupakan kantong-kantong PMI. Hal ini dikarenakan melalui LTSA sejumlah pelayangan pelindungan dan pemberangkatan PMI dapat dilakukan secara terintegrasi, seperti pelayanan kelengkapan dokumen, pelatihan dan tes kesehatan. LTSA juga bertujuan untuk melindungi PMI dari maraknya praktek percaloan. Pendirian LTSA ini sejalan dengan amanat UU PPMI hanya saja belum semua daerah memiliki LTSA terkait pelindungan dan pemenpatan PMI. Seperti di Sumatera Utara, LTSA baru melayani pelayanan perizinan saja. Adapun faktor yang menghambat pembentukan LTSA di sejumlah wilayah adalah masalah kelembagaan yaitu bagaimana hubungan LTSA dengan LTSP yang ada terkait perizinan sehingga adanya peraturan pelaksana yang mengatur LTSA sebagai turunan dari UU PPMI menjadi sangat penting untuk memperjelas masalah kelembagaan tersebut. Selain itu adanya ego sektoral terkait kewenangan yang dimiliki instansi tertentu membuat tidak semua instansi yang terlibat dengan perlindungan PMI mau bergabung dengan LTSA. Keberadaan peraturan pelaksana dalam hal ini PP sesuai amanat Pasal 38 ayat (4) UU PPMI sangat penting untuk menjembatani masalah kelembagaan dan ego sektoral. Beberapa daerah telah berinisiatif membentuk LTSA yang terintegrasi dengan Mall Pelayanan Publik, seperti LTSA Banyumas, Banyuwangi, Kebumen, Batang, dan Pamekasan. Ada juga LTSA yang khusus melayani PMI saja yaitu LTSA Cirebon, Indramayu, dan Subang. ${ }^{44}$

\section{B. Selama Bekerja}

UU PMI menyederhanakan proses perpanjangan perjanjian kerja dengan tidak membatasi jangka waktu perjanjian dan

44 Tempo.co, 24 Februari 2020, "Tingkatkan Pelindungan Pekerja Migran, Kemnaker Bentuk LTSA di Daerah”, https://nasional.tempo.co/read/1311662/tingkatkanpelindungan-pekerja-migran-kemnaker-bentuk-ltsa-didaerah/full\&view $=$ ok, diakses tanggal 2 Agustus 2020. menyerahkannya pada kesepakatan para pihak. Perpanjangan perjanjian kerja juga dapat dilakukan di negara tujuan penempatan tanpa harus kembali ke Indonesia. Sehingga tidak membebani PMI dengan biaya kepulangan. Hanya saja proses ini membutuhkan kecermatan dari perwakilan di negara tujuan untuk menghindari terjadinya eksploitasi terhadap PMI karena sesungguhnya pekerja termasuk pada golongan rentan yang harusnya mendapat pelindungan lebih dari negara. Untuk membantu perwakilan melakukan pelindungan pada PMI maka UU PPMI telah berupaya memperkuat peran atase ketenagakerjaan terkait pendataan dan pendaftaran PMI, verifikasi terhadap mitra dan pemberi kerja, pengumpulan informasi kerja dan peningkatan hubungan bilateral dengan negara penempatan dalam rangka pelindungan terhadap PMI. Peran atase menurut UU PPMI tentunya sangatlah penting. Untuk memperkuat peran atase, UU PPMI mendelegasikan pengaturan tugas dan kewenangan atase kepada presiden melalui Perpres. Akan tetapi hingga saat ini Perpres terkait Atase Ketenagakerjaan belum juga terbit. Akibatnya, Jumlah atase juga tidak mengalami banyak perubahan dari 9 atase ketenagakerjaan dan 2 staf teknis (2017) hanya bertambah menjadi 11 (sebelas) atase ketenagakerjaan (2020). ${ }^{45}$

Pada masa Covid-19, peran dari atase menjadi sangat penting terutama untuk mendekati negara penempatan supaya memberikan pelindungan bagi PMI dari dampak Covid-19. PMI dilaporkan mengalami banyak permasalahan di luar negeri. Berdasarkan survei yang dilakukan oleh Human Rights Working Group (HRWG), Serikat Buruh Migran Indonesia (SBMI) dan Jaringan Buruh Migran (JBM) terhadap 149 PMI dari 9 (sembilan) negara, permasalahan yang dihadapi PMI pada saat Covid -19 dibagi atas 3 faktor yaitu negara

45 Kemenaker, 10 Mei 2020, "Menaker Ida: 587 Pekerja Migran Indonesia Terpapar Covid-19”, https://kemnaker. go.id/news/detail/menaker-ida-587-pekerja-migranindonesia-terpapar-covid-19, diakses tanggal 3 Agustus 2020. 
tujuan, jenis pekerjaan dan gender. ${ }^{46}$ Pada negara yang kebanyakan PMI bekerja sebagai buruh pabrik dan konstruksi banyak PMI yang mengalami gaji tidak dibayar. Seperti terjadi di Malaysia dan Arab Saudi. Bahkan di Arab Saudi sekitar 54\% responden mengalaminya. Sedangkan pada negara yang PMI kebanyakan bekerja pada sektor informal seperti Singapura dan Hongkong, mengalami penambahan beban kerja, pembatasan mobilitas, hak libur, depresi dan tidak mendapat upah lembur. Selain itu mereka mengalami keterbatasan akses kesehatan, informasi, sarana medis, dan obatobatan. Mereka juga mengalami ketakutan apabila pandemik berlangsung lama maka mereka akan mengalami PHK. PMI yang bekerja pada sektor konstruksi kebanyakan mengalami masalah dengan pembayaran gaji. Sedangkan PMI yang bekerja pada sektor manufaktur seperti Taiwan dan Korea Selatan tidak diizinkan keluar rumah sehingga mengalami gangguan psikis. Penguatan peran perwakilan di negara penempatan menjadi salah satu rekomendasi dari HRWG, SBMI dan JBM. Oleh karena itu, pada masa pandemik ini harusnya pemerintah segera mengeluarkan Perpres untuk memperkuat peran atase ketenagakerjaan dalam membantu kinerja perwakilan menangani berbagai permasalahan yang timbul akibat Covid-19.47

Perbudakan ABK juga menjadi permasalahan pelindungan PMI. UU PPMI telah secara jelas memasukkanPMIpelautawakkapaldan perikanan sebagai bagian PMI yang harus mendapatkan pelindungan. Pembuat UU menyadari bahwa banyak aturan dan kepentingan yang berkaitan dengan PMI pelaut ini. Oleh karena itu khusus untuk PMI pelaut, UU PPMI mendelegasikan pelindungan dan penempatan kepada PP. PP ini termasuk PP yang belum terbentuk hingga

46 HRWG, 10 Mei 2020, "Siaran Pers Dampak COVID-19 terhadap PMI: Dari PHK, Gaji Tidak Dibayar, Takut Ditangkap, Sampai Kerja Ekstra Tanpa Tambahan Insentif', https://hrwg.org/2020/05/10/siaran-persdampak-covid-19-terhadap-pmi-dari-phk-gaji-tidakdibayar-takut-ditangkap-sampai-kerja-ekstra-tanpatambahan-insentif,/ diakses tanggal 3 Agustus 2020. saat ini. Padahal kasus yang menimpa PMI pelaut Indonesia marak terjadi. Baru-baru ini diberitakan terjadi pembuangan jenazah tiga PMI ABK Indonesia oleh kapal Longxing 629 China. Pada April 2020, Greenpeace Asia Tenggara melaporkan terdapat 34 kasus yang melibatkan awak kapal Indonesia dengan 4 permasalahan utama yaitu penipuan, penahanan gaji, kekerasan fisik dan seksual. ${ }^{48}$ Banyaknya kasus yang dialami PMI pelaut menyebabkan lahir istilah perbudakan PMI pelaut. Berbagai kasus perbudakan di laut ini hendaknya dapat mendorong pemerintah untuk segera menerbitkan PP terkait pelindungan dan penempatan PMI pelaut awak kapal dan perikanan.

Pada masa pandemik ini juga menjadi momen bagi BPJS Ketenagakerjaan untuk dapat membuka perwakilan layanan di luar negeri atau setidaknya menjalankan amanah Pasal 42 Permenaker No. 18 Tahun 2018 yang menyatakan, BPJS Ketenagakerjaan dapat bekerjasama dengan atase ketenagakerjaan atau staf teknis serta lembaga jaminan sosial lain di negara tujuan penempatan untuk meningkatkan pelayanan pada PMI. Pada Mei 2020, berdasarkan data atase dari 11 negara, 587 PMI terpapar Covid-19, positif sebanyak 224 orang dan meninggal 10 orang dan sisanya masuk karantina. ${ }^{49}$ Berdasarkan hasil survei HRWG dkk., PMI pada sejumlah negara telah mengeluhkan penanganan Covid-19 di negara penempatan dan menginginkan adanya perwakilan dari BPJS di luar negeri. ${ }^{50}$ Harusnya

48 Anisa Erou, 2 April 2020, "Perlindungan Awak Kapal Perikanan sebagai Pekerja Migran Indonesia”, https:/www.greenpeace.org/indonesia/cerita/4918/ perlindungan-awak-kapal-perikanan-sebagai-pekerjamigran-indonesia/, diakses tanggal 2 Agustus 2020.

49 Kemenaker, 10 Mei 2020, "Menaker Ida: 587 Pekerja Migran Indonesia Terpapar Covid-19”, https://kemnaker. go.id/news/detail/menaker-ida-587-pekerja-migranindonesia-terpapar-covid-19, diakses tanggal 3 Agustus 2020.

50 HRWG, 10 Mei 2020, "Siaran Pers Dampak COVID-19 terhadap PMI: Dari PHK, Gaji Tidak Dibayar, Takut Ditangkap, Sampai Kerja Ekstra Tanpa Tambahan Insentif", $\quad$ https://hrwg.org/2020/05/10/siaran-persdampak-covid-19-terhadap-pmi-dari-phk-gaji-tidakdibayar-takut-ditangkap-sampai-kerja-ekstra-tanpatambahan-insentif,/ diakses tanggal 3 Agustus 2020. 
negara berusaha hadir untuk melindungi para PMI yang sakit ini meski sejumlah negara penempatan, seperti Singapura telah menyatakan komitmennya untuk merawat pasien warga negara asing termasuk PMI.

\section{Setelah Bekerja}

Pelindungan setelah bekerja diatur berdasarkan PP yang hingga saat ini belumlah ada. Pelindungan tersebut antara lain melingkupi kepulangan ke daerah asal, pemberdayaan, rehabilitasi dan reintegrasi. Saat ini terkait dengan kepulangan PMI, pemerintah tidak hanya mengalami permasalahan terkait proses pemulangan PMI bermasalah atau non prosedural yang masih marak terjadi akibat belum berjalannya UU PPMI akan tetapi juga dihadapkan pada pemulangan PMI yang terdampak Covid-19. Berdasarkan data BP2MI, selama Covid-19 badan telah memulangkan sebanyak 162 ribu PMI (28 Juni 2020). Adapun prosedur pemulangan mengikuti protokol kesehatan yaitu sebelum masuk ke wilayah demarkasi, PMI terlebih dahulu menjalani tes Covid-19. Mereka kemudian menjalani masa karantina sesuai wilayah masuknya. Wilayah masuk yang telah ditentukan adalah Jakarta, Bali, dan Batam. Apabila PMI masuk ke Jakarta, maka akan dikarantina di Wisma Atlet. ${ }^{51}$ Bagi para PMI yang terbukti positif Covid-19, maka akan segera ditempatkan di rumah sakit darurat. Salah satunya adalah di rumah sakit khusus Covid-19 di Pulau Galang, Batam. Namun penerapan prosedur kesehatan terhadap PMI belum sepenuhnya berhasil karena dilaporkan terjadi penularan Covid-19 dari PMI yang baru kembalidariluar negeri. Sepertiyang terjadidiBali yang mana PMI melakukan karantina mandiri namun malah menginfeksi orang disekitarnya. ${ }^{52}$

$51 \quad$ Fahmi Ahmad Burhan, 28 Juni 2020, "Sudah 162 Ribu PMI Pulang Imbas Covid-19, BP2MI Ungkap Travel Gelap", https://katadata.co.id/muhammadridhoi/berita/ 5ef8274b99ef1/sudah-162-ribu-pmi-pulang-imbas-covid-19bp2mi-ungkap-travel-gelap, diakses tanggal 3 Agustus 2020.

52 Merdeka.com, 28 April 2020, "Kasus Transmisi Lokal di Bali Akibat Terinfeksi Pekerja Migran Indonesia”, https:// www.merdeka.com/peristiwa/kasus-transmisi-lokal-dibali-akibat-terinfeksi-pekerja-migran-indonesia.html, diakses tanggal 3 Agustus 2020.
Transmisi Covid-19 oleh PMI ini memang mungkin terjadi karena Kementerian Kesehatan baru mengeluarkan prosedur kepulangan pada bulan Mei 2020 setelah sebelumnya banyak PMI dibiarkan kembali ke daerah asal tanpa dilakukan pengecekan terlebih dahulu. Disinilah pentingnya PP pelindungan PMI terutama terkait wabah. Berdasarkan UU PPMI apabila terjadi wabah penyakit seperti saat ini maka yang bertanggung jawab mengurus kepulangan adalah pemerintah pusat, pemerintah provinsi, kabupaten/kota. Oleh karena itu harusnya pengurusan PMI terdampak wabah memang tidak hanya menjadi tanggung jawab perintah pusat akan tetapi juga daerah seperti diatur dalam UU PPMI.

Berkaitan dengan pemberdayaan, rehabilitasi dan reintegrasi terhadap PMI dan keluarganya pemerintah mengeluarkan program desmigratif namun program tersebut tidak berjalan dengan baik karena keterbatasan anggaran selain itu dukungan dari kementerian/ instansi lainnya juga sangat terbatas. Dasar hukum desmigratif adalah Keputusan Menteri Ketenagakerjaan No. 59 Tahun 2017 tentang Penyelenggaraan Desa Migran Produktif yang telah diubah Permenaker No. 2 Tahun 2019 tentang Pemberdayaan Komunitas Pekerja Migran di Desa Migran Produktif. Dasar hukum Permen dan Kepmen tentunya hanya dapat menjangkau internal Kementerian Ketenagakerjaan dan tidak dapat menjangkau instansi lain. Padahal untuk mewujudkan suatu desa migran produktif perlu kerjasama dari berbagai pihak seperti Kementerian Kesehatan, Kementerian Perdagangan, Kementerian UMKM. Oleh karena itu supaya proses pemberdayaan terhadap PMI dan keluarganya dapat berjalan dengan baik pemerintah perlu segera mengundangkan PP terkait Pelindungan Pekerja Migran yang didalamnya terdapat penjabaran tentang pelindungan sosial, hukum dan ekonomi bagi para PMI termasuk juga tugas dan tanggung jawab pemerintah daerah terkait pemberdayaan PMI. 
VI. Upaya Mengatasi Pelanggaran Batas Waktu Pembentukan Peraturan Pelaksana dari UU PPMI

UU merupakan produk hasil kesepakatan antara pemerintah dengan DPR. Dalam pembahasan UU PPMI, pemerintah dan DPR telah bersepakat pembentukan sejumlah peraturan pelaksana demi terjaminnya pelaksaanaan UU dengan baik. Dalam UU PPMI pemerintah diberi waktu 2 (dua) tahun semenjak UU diundangkan dan pemerintah menyepakatinya. Harusnya pemerintah bertanggung jawab terhadap komitmen yang telah dibangun dalam membentuk UU PPMI. Sehingga apabila pemerintah melanggar kesepakatan tersebut DPR dapat menagih komitmen pemerintah melalui fungsi pengawasan. Fungsi pengawasan merupakan salah satu fungsi yang dimiliki DPR dalam melaksanakan tugas pengawasan atas pelaksanaan UU dan APBN..$^{53}$

Berkaitan dengan proses pembentukan peraturan pelaksana dari UU PPMI, DPR telah sejak awal mengawal proses pembentukan peraturan pelaksana. Timwas PMI beberapa kali memperingatkan pemerintah supaya segera membentuk aturan pelaksana. Apabila terdapat kendala misalnya adanya ego sektoral dari instansi tertentu. DPR memberikan kesempatan kepada para pihak untuk dapat memberikan pandangannya melalui sejumlah instrumen yang ada seperti RDP dan RDPU. Melalui proses tersebut pemerintah juga diharapkan dapat lebih transparan dalam proses pembahasan dan masyarakat juga dapat mengamati serta memberikan masukan terhadap proses tersebut.

Beberapa instansi terkait tidak menyianyiakan kesempatan yang diberikan DPR, pada beberapa rapat yang dilakukan mereka secara beritikad baik menghadirinya dan memaparkan proses perkembangan dan berbagai permasalahan yang terjadi dalam proses pembahasan. Sehingga dalam setiap rapat

\footnotetext{
53 Berdasarkan Pasal 69 ayat (1), Pasal 70 ayat (3) dan Pasal 72 UU No. 17 Tahun 2014 tentang Majelis Permusyawaratan Rakyat, Dewan Perwakilan Rakyat, Dewan Perwakilan Daerah, dan Dewan Perwakilan Rakyat Daerah.
}

yang berlangsung mereka saling memberikan masukan terkait proses dan permasalahan yang ada, seperti pada saat pemerintah kesulitan dalam mengintegrasikan kelembagaan dari LTSA di daerah, Kementerian Dalam Negeri memberikan solusi dalam rapat. Hanya saja proses pembahasan yang cukup alot di tubuh internal pemerintah membuat pemerintah tidak dapat sepenuhnya dapat menyelesaikan target legislasi tepat waktu. Apalagi terkait pandemik Covid-19 menjadi salah satu alasan pemerintah untuk menyelesaikan komitmennya dalam pembahasan peraturan pelaksana.

DPR sebetulnya memiliki hak interpelasi yaitu hak meminta pejabat negara, pemerintah, badan hukum atau warga masyarakat untuk dapat memberikan keterangan tentang sesuatu hal yang perlu ditangani demi kepentingan bangsa dan negara terutama jika dinilai ada kebijakan pemerintah yang telah merugikan masyarakat. ${ }^{54}$ Selain interpelasi terdapat juga hak angket dan hak menyatakan pendapat yang ketiganya merupakan instrumen hukum yang dapat dimanfaatkan oleh DPR dalam melakukan fungsi pengawasan. ${ }^{55} \mathrm{Hak}$ angket merupakan hak DPR melakukan penyelidikan bila ada dugaan adanya kebijakan pemerintah yang bertentangan dengan peraturan perundang-undangan. Hak interpelasi dan hak angket dapat ditindaklanjuti dengan hak menyatakan pendapat. ${ }^{56}$ Hak-hak tersebut

\footnotetext{
$54 \quad$ Sunardi, "Fungsi Pengawasan DPR terhadap Pemerintah dalam Mewujudkan Good Governance dan Clean Government Ditinjau dari Perspektif Politik Hukum", Jurnal Meta Yuridis, Vol.1 No. 2, 2018, hal. 24.

55 Berdasarkan Pasal 74 ayat (1) dan ayat (3) UU No. 2 Tahun 2018 tentang Perubahan Kedua atas 17 Tahun 2014 tentang Majelis Permusyawaratan Rakyat, Dewan Perwakilan Rakyat, Dewan Perwakilan Daerah, dan Dewan Perwakilan Rakyat Daerah diatur bahwa DPR dapat menggunakan hak interpelasi, hak angket, hak menyatakan pendapat atau hak anggota DPR mengajukan pertanyaan, apabila terdapat pengabaian atau tidak dilaksanakannya rekomendasi yang sebelumnya telah diberikan DPR melalui mekanisme rapat kerja, RDP, RDPU, rapat panitia khusus, rapat panitia kerja, rapat tim pengawas, atau rapat tim lain yang dibentuk oleh DPR.

56 Pasal 79 UU No. 17 Tahun 2014 tentang Majelis Permusyawaratan Rakyat, Dewan Perwakilan Rakyat, Dewan Perwakilan Daerah, dan Dewan Perwakilan Rakyat Daerah.
} 
dapat diterapkan oleh DPR apabila pemerintah tidak juga menyelesaikan peraturan pelaksaan UU PPMI karena dari hasil pengawasan, UU PPMI tidak dapat berlaku apabila belum ada aturan pelaksananya meski secara hukum UU PPMI telah berlaku saat diundangkan.

\section{Penutup}

\section{A. Simpulan}

UU PPMI banyak mengamanatkan pembentukan peraturan pelaksana setidaknya ada 28 pasal dalam UU tersebut yang mengatur terkait pendelegasian. Oleh pemerintah kemudian disimplifikasi menjadi 13 (tiga belas) peraturan pelaksana saja. Hingga saat ini baru 7 (tujuh) peraturan pelaksana yang terealisasi. Tiga diantaranya diundangkan tepat waktu sedangkan 4 peraturan pelaksana mengalami keterlambatan dan sisanya 6 (enam) peraturan belum diundangkan sama sekali. Adapun penyebab keterlambatan dan belum diundangkannya sejumlah peraturan karena masalah teknis dan substansi. Masalah teknis terkait banyaknya pendelegasian aturan, beragamnya instansi yang terlibat dan keterbatasan sarana dan prasarana pendukung peraturan pelaksana. Adapun masalah substansi terkait adanya tumpang tindih pengaturan yang menyebabkan terjadinya tumpang tindih kewenangan antar instansi dan tumpang tindih pengaturan dengan peraturan perundangundangan lainnya. Hal ini berdampak negatif terhadap pelindungan PMI. Dampak pada masa sebelum bekerja, antara lain masih adanya penampungan, dan biaya penempatan. Pada masa bekerja masih minimnya perlindungan PMI yang terdampak Covid-19 dan adanya praktek perbudakan terhadap PMI pelaut. Sedangkan pada masa sesudah bekerja berdampak pada minimnya perlindungan pemulangan PMI terdampak Covid-19 dan kurang berjalannya program pemberdayaan. Oleh karenanya, semua peraturan pelaksana dari UU PPMI perlu segera diundangkan. DPR perlu berupaya mendesak pemerintah untuk segera mengundangkan berbagai aturan pelaksana tersebut.

\section{B. Saran}

Masih ada 6 (enam) peraturan pelaksana dari UU PPMI yang belum diundangkan termasuk PP terkait Pelindungan PMI. Hal ini berpengaruh pada proses pelindungan terhadap PMI. Oleh karena itu, DPR perlu lebih meningkatkan upaya pengawasan baik melalui Tim Pengawas PMI maupun melalui Komisi IX. Peran DPR amat dibutuhkan dalam pembahasan peraturan pelaksana UU PPMI karena UU dan peraturan pelaksananya ini melibatkan banyak instansi, kepentingan dan ego sektoral. Melalui instrumen pengawasan DPR dapat mendorong pemerintah untuk dapat meningkatkan koordinasi terutama dalam menyusun peraturan pelaksana dan membuat proses pembahasannya menjadi lebih transparan dan diketahui masyarakat melalui sejumlah instrumen yang dimiliki DPR RI.

\section{Daftar Pustaka}

\section{Jurnal}

Andayana, Made Ngurah Demi. "Penyimpangan Kebijakan Pengiriman TKI Ke Luar Negeri”. Journal of Management (SME's). Vol. 9 No. 2, 2019.

Benuf, Kornelius \& Muhamad Azhar. "Metodologi Peneltian Hukum sebagai Instrumen Mengurangi Permasalahan Hukum Kontemporer". Jurnal Gema Keadilan. Vol 7 Edisi 1. Juni 2020.

Ginting, Lia Melanie, Elisa Susanti, dan Asep Sumaryana. "Implementasi Pelayanan Terpadu Satu Pintu Non-Perizinan di Ukur dari Kepuasan Masyarakat dengan Menggunakan Indeks Kepuasan Masyarakat", Responsive, Vol. 1 No. 2 Desember 2018.

Larasati, Donna Savira. "Peran Pemerintah Indonesia dalam Melindungi Hak TKI dari Praktik Underpayment di Hongkong". Journal of International Relations. Vol. 4, No. 3. 2018. 
Muflichah, Siti \& Rahadi Wasi Bintoro. "Trafficking: Suatu Studi Tentang Perdagangan Perempuan Dari Aspek Sosial, Budaya Dan Ekonomi Di Kabupaten Banyumas". Jurnal Dinamika Hukum. Vol. 9, No. 1, Januari 2009.

Octaviani, Fadilla. "Perbaikan Tata Kelola Pelindungan Abk Indonesia Di Kapal Ikan Asing,I ndonesia Ocean Justice Initiative". Policy Brief 3. Juni 2020.

Purwangka, Fis. "Model Pengelolaan Keselamatan Kerja Nelayan di Pelabuhanratu Kabupaten Sukabumi”. Jurnal IPTEKS PSP. Vol. 5 No. 9, April 2018.

Simamora, Janpatar. "Analisa Yuridis terhadap Model Kewenangan Judicial Review di Indonesia”. Mimbar Hukum. Vol. 25, No. 3. Oktober 2013.

Sjarif, Fitriani Ahlan. "Gaya Perumusan Kalimat Perintah Pembentukan Peraturan yang Menjalankan Delegasi dari UndangUndang di Indonesia". Pakuan Law Review. Vol. 3, No. 2. 2017.

Sukardi \& E. Prajwalita Widiati. "Pendelegasian Pengaturan oleh Undang-Undang kepada Peraturan yang Lebih Rendah dan Akibat Hukumnya”. Yuridika. Vol. 25, No. 2. 2010.

Sunardi. "Fungsi Pengawasan DPR terhadap Pemerintah dalam Mewujudkan Good Governance dan Clean Government Ditinjau dari Perspektif Politik Hukum”. Jurnal Meta Yuridis. Vol.1, No. 2. 2018.

Syahlan. "Rekonstruksi Penataan Peraturan Perundang-Undangan Pasca Berlakunya Undang-Undang Nomor 12 Tahun 2011 tentang Pembentukan Peraturan Perundang-Undangan". Wacana Hukum. Vol. 25, No. 1. Desember 2019.

Syamsuddin \& Gunadi Setyo Utomo. "Permasalahan Buruh Migran Indonesia pada Sektor Publik". Jumal PKS. Vol 15, No 3. September 2016.

\section{Buku}

Ashshofa, Burhan. Metode Penelitian Hukum. Jakarta: PT Rineka Cipta, 2013.

Sadiawati, Diani dkk. Kajian Reformasi Regulasi di Indonesia: Pokok Permasalahan dan Strategi Penanganannya. Jakarta: PSHK, 2019.

Soekanto, Soerjono. Faktor-Faktor yang Mempengaruhi Penegakan Hukum. Jakarta: PT RajaGrafindo Persada, 2004.

\section{Makalah}

BNP2TKI. "Progress Pelaksanaan UU No 18 Tahun 2017 Tentang Pelindungan Pekerja Migran Indonesia". Bahan RDP Timwas PMI DPR. Jakarta, 16 Januari 2019.

BP2PMI. "Data Penempatan dan Pelindungan Pekerja Migran Indonesia Tahun 2019”. Jakarta: Pusat Penelitian Pengembangan dan Informasi BP2PMI, 2020.

"Isu Krusial Pada Tata Kelola Pekerja Migran". Hasil Konsinyering Pembahasan RUU PPMI. Kopo, 16 April 2017.

Kemenaker. "Perkembangan Penyusunan Pelaksanaan Undang-Undang Nomor 18 Tahun 2017 tentang Pelindungan Pekerja Migran Indonesia”. Bahan RDP Timwas PMI DPR. Jakarta, 16 Januari 2019.

"Laporan Akhir Pelaksanaan Tugas Timwas DPR RI terhadap Perlindungan Tenaga Kerja Indonesia”, DPR RI, Jakarta, September 2014.

"Laporan Tim Pengawas DPR RI terhadap Pelindungan Pekerja Migran Indonesia", DPR RI, Jakarta, 2019.

\section{Pustaka dalam Jaringan}

Burhan, Fahmi Ahmad. "Sudah 162 Ribu PMI Pulang Imbas Covid-19, BP2MI Ungkap Travel Gelap". 28 Juni 2020. https://katadata.co.id/muhammadridhoi/ berita/5ef8274b99ef1/sudah-162-ribu-pmipulang-imbas-covid-19-bp2mi-ungkaptravel-gelap, diakses tanggal 3 Agustus 2020. 
Erou, Anisa. "Perlindungan Awak Kapal Perikanan sebagai Pekerja Migran Indonesia”. 2 April 2020. https://www. greenpeace.org/indonesia/cerita/4918/ perlindungan-awak-kapal-perikanansebagai-pekerja-migran-indonesia/, diakses tanggal 2 Agustus 2020.

HRWG. "Siaran Pers Dampak COVID-19 terhadap PMI: Dari PHK, Gaji Tidak Dibayar, Takut Ditangkap, Sampai Kerja Ekstra Tanpa Tambahan Insentif'. 10 Mei 2020. https:/hrwg.org/2020/05/10/ siaran-pers-dampak-covid-19-terhadappmi-dari-phk-gaji-tidak-dibayar-takutditangkap-sampai-kerja-ekstra-tanpatambahan-insentif/, diakses tanggal 2 Agustus 2020.

Infopena.com. "GARUDA Sulteng Apresiasi Penggerebekan Penampungan Calon Pekerja Migran Oleh BP2MI". 4 Mei 2020. https://www.infopena.com/blog/ garuda-sulteng-apresiasi-penggerebekanpenampungan-calon-pekerja-migran-olehbp2mi/, diakses tanggal 2 Agustus 2020

Kemenaker.go.id. "Menaker Ida: 587 Pekerja Migran Indonesia Terpapar Covid-19”. 10 Mei 2020. https://kemnaker.go.id/news/ detail/menaker-ida-587-pekerja-migranindonesia-terpapar-covid-19, diakses tanggal 3 Agustus 2020.

Kontan.co.id. "Kemenaker: Sebanyak 48,5\% PMI bekerja di sektor formal di 2019". 11 Februari 2020. https://nasional.kontan. co.id/news/kemenaker-sebanyak-485-pmibekerja-di-sektor-formal-di-2019, diakses tanggal 27 September 2020.
Merdeka.com. "Kasus Transmisi Lokal di Bali Akibat Terinfeksi Pekerja Migran Indonesia”. 28 April 2020 https://www. merdeka.com/peristiwa/kasus-transmisilokal-di-bali-akibat-terinfeksi-pekerjamigran-indonesia.html, diakses tanggal 3 Agustus 2020.

Safari. "Dinilai Hambat Kewenangan MUI, IHW Judicial Review PP No 31/2019 ke MA“. 24 Mei 2019. https://www. harianterbit.com/nasional/read/106759/ Dinilai-Hambat-Kewenangan-MUI-IHW Judicial-Review-PP-No-312019-ke-MA, diakses tanggal 27 Juli 2020.

Syafii, Imam. "PP Penempatan dan Pelindungan Pelaut Indonesia di Luar Negeri Harus Mampu Mengatasi Tumpang Tindih Regulasi”. 16 Desember 2020. https://ppi.or.id/editorial/ pp-penempatan-dan-pelindungan-pelautindonesia-di-luar-negeri-harus-mampumengatasi-tumpang-tindih-regulasi/, diakses tanggal 2 Agustus 2020.

Tempo.co. "Tingkatkan Pelindungan Pekerja Migran, Kemnaker Bentuk LTSA di Daerah". 24 Februari 2020. https://nasional. tempo.co/read/1311662/tingkatkanpelindungan-pekerja-migran-kemnakerbentuk-ltsa-di-daerah/full\&view $=$ ok, diakses tanggal 2 Agustus 2020

Wahyudi, Ridwan. "Pelindungan Komprehensif bagi Pekerja Migran Indonesia di Hong Kong”. 12 Februari 2020. https://buruhmigran.or.id/2020/02/12/ pelindungan-komprehensif-bagi-pekerjamigran-indonesia-di-hong-kong/, diakses tanggal 2 Agustus 2020. 